\title{
Henry David Thoreau, The Beginnings of Fast Capitalism
}

\author{
Charles Lemert
}

\section{Introduction}

Henry David Thoreau (1817-1862) was born in Concord, Massachusetts, where he died in his 42nd year. Save for a few years infancy when his family lived in Chelmsford, then Boston, and his years at Harvard College, Thoreau lived in Concord his whole life. Concord was home even when he was away on his well-known short trips-to the Maine Woods and Mt Katahdin, Mt Monadnock and Mt Washington, a trip in 1850 to Canada and the St. Lawrence River, North on the Concord and Merrimack Rivers with his brother, Fire Island to search for the remains of Margaret Fuller who drowned offshore with her Italian husband and their child, up and down the River between Wayland and Billerica for a commissioned survey of all the bridges on the Concord River, and of course for his many lyceum lectures throughout the Northeast.

It hardly needs to be said that Thoreau is famous the world over for Walden, which began with his declaration of independence from the world as it was becoming:

When I wrote the following pages, or rather the bulk of them, I lived alone in the woods, a mile from any neighbor, in a house which I built myself, on the shore of Walden Pond, in Concord, Massachusetts, and earned my living by the labor of my hands only.

Though indeed he returned to civilization_and regularly visited town while living by the Pond, once to get arrested for failure to pay taxes-life at Walden Pond from 1845 to 1847 stood for him as the measuring rod for life as it ought to be lived, as distinct from lives as they were lived in town and beyond. One of better-known lines from the book is a sharp criticism of civilized life: "The mass of men lead lives of quiet desperation."

Walden was anything but a personal memoir. In fact, Thoreau used his two years, two months, and two days in the woods by a pond as a token of everything in the world that should be avoided. In 1847, he returned to live in town where he solidified his friendships with Ralph Waldo Emerson, Margaret Fuller, and the remarkable group of writers and intellectuals, including Louisa May Alcott and Nathaniel Hawthorne, which made Concord the town that gave Susan Cheever the title to her book American Bloomsbury. Thoreau was in the thick of all this, even while attending, as best he could, to a degree of solitary life.

Walden is a work of critical social theory. But of what? There is no single answer. Among his targets were slavery, especially the Fugitive Slave Law; mundane life that was preoccupied with news of the wider world; the infusion of the modern-thinking people who thought nothing of the native Tahatawan people who had farmed the land for hundreds of years; and of the first English settlers who brought with them premodern farming methods. Then, too, Concord was already becoming what it is now - a suburb of Boston, linked to the city by train and trails. Laura Dassow Walls puts this range of critical topics clearly in her Thoreau: A Life: 
...[T]horeau witnessed the final collapse of this two-hundred-year old system. When he went to Walden Pond in 1845 change was visible everywhere: the new railroad cut right across Walden's prettiest cove; the subsistence farms failing, eroded away by the global marketplace. Few of his neighbors still ate "rye ' $n$ ' Injun" bread, or wore homespun "linsey-woolsey." Now they cooked on stoves, heated with coal, built with Maine white pine, cut their woodlots to fuel the railroads, planting them in English hay to feed new breeds of cattle they slaughtered for the Boston market and packed for the West Indies. They filled their pantries with China tea, slave-grown sugar, prairie wheat flour, tropical oranges and pineapples; they wore Georgia cotton, China silks, Canada furs, British woolens.i

So, in one sense, Thoreau was a critic of the modern world as it was invading Concord and, by implication, the simpler life in small towns and country villages.

In Walden, Thoreau is clear as to his purpose by the Pond:

I went to the woods because I wished to live deliberately, to front only the essential facts of life, and see if I could not learn what it had to teach, and not, when I came to die, discover that I had not lived.

This is the familiar declaration from the second chapter Where I Lived, and What I Lived For. Walden that began with an introduction, Economy, in which he described in precise detail how cheaply he could live in a cabin made by his own hands. Economy must be read as a stern critique of capitalism's dangerous excesses: "Most of the luxuries, and many of the so-called comforts of life, are not only not indispensable, but positive hindrances to the elevation of mankind." Comments like this are one reason that Thoreau is rightly respected for speaking out on important public issues in his day in shorter essays: Slavery in Massachusetts, A Plea for Captain John Brown, and Civil Disobedience (an attack on taxation policies). But the most systematic of his critical theories is buried in a controversial chapter in Walden, The Bean-Field. Thoreau was clear about his narrative strategy. Walden was composed so as to condense his more than two years at the Pond into a single year of seasons. A first glance at the table of contents can disguise this story line under all the other of its narrative lines: a series of random topics: Reading, Sounds, Solitude, Visitors; an apparent series on local geography: The Bean-Field, The Village, The Ponds, Baker Farm; then, oddly: Higher Laws, which turns out to be a low-key transcendentalist exposition; after which Brute Neighbors is an unusual sequel to Higher Laws because it is a most particular commentary on his observations of the vicissitudes of animal life surrounding the Pond. Then, finally, amid all this the careful reader discerns the seasonal line with chapters on Housewarming, Winter Visitors, Winter Animals, The Pond in Winter, and Spring. Housewarming is the autumnal essay in which the focus is on the chimney he built, and the wood gathered for heat for the coming winter. Then, in time, the story of this year passed on to spring, unqualifiedly Spring. But, if the underlying scheme of the book is the four seasons, where is summer?

In this story of many twists and turns, summer is covered by the book's most controversial chapter The Bean-Field that turns out to be the hook on which hangs the fictional frame of Walden as an annual cycle of events in his story of Thoreau's life apart from civil society. The Bean-Field begins, however, in a strange way: "Meanwhile my beans, the length of whose rows, added together, was seven miles already planted...." Seven miles of beans in two and a half acres? Obviously far beyond what anyone could eat even in a year. Plus which, his bean field by the side of the road exposed him to rebuke from passersby: "Beans too late! Peas so late!"-comments, he means to say, that were more than passing observations.

The field side complaints are at the center of the controversy. Thoreau wrote the chapter as a response to Henry Colman, a one-time Unitarian minister who turned to the surveying of crop lands in Massachusetts, whereupon he became an authority on agriculture in the East. Colman intended to justify farming in Massachusetts by a method Thoreau strenuously opposed. Colman argued that farmers, even in the East, could be more productive if they would learn to apply scientific methods of cultivation. Thoreau would have nothing of it. His bean field was, he wrote, "one field not in Mr. Colman's report." In a journal entry of March 7, 1847, Thoreau explains that his attitude toward the field was also a response to actual scientific farmers who in the winter swooped down "on our pond-with many car-loads of ungainly-looking farming tools, sleds, ploughs, drill-barrows, turf-knives, spades, saws, rakes, and each 
man was armed with a double-pointed pike-staff... as if they were bent on making this a model farm." The Bean-Field chapter is only apparently a simple story of farming in the summer of 1846, when in fact it is a political manifesto of the extent to which then modernizing science is ruining local well-being.

Thus, it is The Bean-Field that appears in Walden as the summer anchor in its annual cycle of life on the pond. The Bean-Field turns out be a running critical assault not just on Henry Colman's model farm but even more on the coming of scientific agribusiness. The chapter ends:

The true husbandman will cease from anxiety, as the squirrels manifest no concern whether the woods will bear chestnuts this year or not and finish his labor with every day and sacrificing in his mind not only his first but his last fruits.

No one would blame those who read this as hopelessly naive. But then again, this could be radical antiAnthropocene politics.

Walden was published in 1854 when the Kansas-Nebraska Act fixed the nation's destiny on a civil war of four bloody years in which the industrial capitalism on the American North defeated and all but ended the feudal system of the enslaved South that, in its way, was a form of industrial agribusiness when the cotton gin mechanized cotton production. The nation had long before been headed toward this conjuncture wherein modern industrial capitalism changed everything - not just in America but the world over. It was then that the Anthropocene that, though it had to wait more than a century for its name, thrust itself on a human world, a world Thoreau considered less human than it had been. The Anthropocene is a world in which man takes over and dominates the earth, its plant and vegetable life, its animal husbandry, its forests - all of which and more are depleted to the end of their coming destruction. The Anthropocene is post-geological and post-human because it is domination not by free and critical human being but by an avaricious capitalism that cares about nothing but surplus values that abolish living and breathing human values. 